ered them up so they would not be damaged by the traffic. Beck, Carson and I gathered many more in the surrounding grassy areas and stubble fields. The majority of the birds were found south and east of the tower. A total of 216 birds of 28 species was found at the CKCK tower and 77 birds of 18 species at the CHRE tower. A considerable number of injured birds were flushed from the ground. Most of these were able to fly away. Among these were noted a Catbird, Red-eyed Vireos, Northern Waterthrushes, Ovenbirds, Swamp Sparrows, and other warblers and sparrows. The Lumsden tower was also checked but no birds were found there. Table 2 shows the species recovered on September 4.

The Regina weather office reported that during the night when the kill took place the temperature held at $50^{\circ}$, the wind was NW at 20 m.p.h., barometric pressure steady at 951.8. There was a cloud layer at 4,000 feet, and a complete cloud layer at 8,000 feet all night. No rain fell.
Table 2-Birds recovered at TV towers at Regina, September 4, 1964.

\begin{tabular}{|c|c|c|c|}
\hline Species & KCK & CHRE & Total \\
\hline Virginia Rail & & - & 1 \\
\hline Sora & $i$ & 1 & 2 \\
\hline Traill's Flycatcher & 2 & 1 & 2 \\
\hline $\begin{array}{l}\text { Barn Swallow } \\
\text { Swainson's Thrush }\end{array}$ & $\overline{1}$ & $\begin{array}{l}1 \\
6\end{array}$ & $\begin{array}{l}1 \\
7\end{array}$ \\
\hline Gray-cheeked Thrush & - & 1 & 1 \\
\hline Solitary Vireo & 1 & 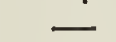 & i \\
\hline Red-eyed Vireo ...- & 30 & 9 & 39 \\
\hline & 2 & 1 & 3 \\
\hline $\begin{array}{l}\text { Warbling Vireo } \\
\text { Black-and-white Warbler }\end{array}$ & $\begin{array}{l}1 \\
3\end{array}$ & 1 & $\begin{array}{l}2 \\
4\end{array}$ \\
\hline Tennessee Warbler & 32 & 6 & 38 \\
\hline Yellow Warbler & 39 & 12 & 51 \\
\hline Magnolia Warbler & 1 & & 1 \\
\hline $\begin{array}{l}\text { Bay-breasted Warbler } \\
\text { Blackpoll Warbler }\end{array}$ & $\begin{array}{l}1 \\
6\end{array}$ & $\begin{array}{l}1 \\
6\end{array}$ & $\begin{array}{r}2 \\
12\end{array}$ \\
\hline Palm Warbler & 1 & - & 1 \\
\hline nbird & 38 & 15 & \\
\hline $\begin{array}{l}\text { Northern Waterthrush } \\
\text { Mourning Warbler }\end{array}$ & 14 & 6 & 19 \\
\hline Yellowthroat - & 5 & & 5 \\
\hline Wilson's Warbler & $\begin{array}{l}3 \\
3\end{array}$ & $?$ & 5 \\
\hline American Redstart & 2 & - & 2 \\
\hline Red-winged Blackbird & 1 & - & 1 \\
\hline Baltimore Oriole & 2 & - & 2 \\
\hline Savannah Sparrow & 1 & 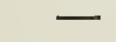 & 1 \\
\hline Sharp-tailed Sparrow & 1 & — & 1 \\
\hline Clay-colored Sparrow -- & 3 & 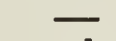 & 3 \\
\hline White-throated Sparrow & & 1 & \\
\hline Lincoln's Sparrow & 14 & 2 & 16 \\
\hline Total & 216 & 77 & 293 \\
\hline
\end{tabular}

\title{
Eared Grebe Colony at Regina, 1964
}

by Fred W. Lahrman, Saskatchewan Museum of Natural History, Regina

For four years we have been watching an Eared Grebe colony grow in numbers at the Regina Waterfowl Park. In 1961, 48 nests were counted (Blue Jay, 19:170-171); in 1962 the colony had a total of 165 nests (Blue Jay, 20:158); and in 1963 a total of 179 (Blue Jay, 22:17). In 1964, the highest count of Eared Grebe nests ever made in the Regina Waterfowl Park was recorded-a count of 300 .

The first Eared Grebe arrived at the Regina Waterfowl Park April 21, 1964, with an influx of Lesser Scaup, being recorded on that date along with one Horned Grebe and one Pied-billed Grebe, by Margaret Belcher. By May 2 , the grebes were established in numbers at the Waterfowl Park. On. May 27 Dot and Doug Wade counted 32 nests scattered in small groups where water plants were available in the area south of the city power house, and on May 30 they counted 122 nests. Strong winds on June 4 washed away some of the nests, but when the Wades checked the colony on June 6 they found active re-building and counted 76 nests east of the power house, with others under construction east of the Broad Street bridge. When I made my count on July 2, there was an impressive total of 300 nests. The heavy rain of .July 3 . destroyed almost all these nests and there was little renesting after. However, many grebes had already hatched and the storm did not harm thèse young birds.

\section{PRAIRIE NEST RECORDS SCHEME}

You are invited to keep nest records for the 1965 season and to submit them to the Prairie Nest Records Scheme. All records should be submitted on nest record cards which can be obtained from the Chairman, Robert Taylor. Those who contributed records in 1964 will receive cards automatically; but all new contributors should write for cards and further instructions about keeping records. Write:

ROBERT R. TAYLOR,

Chairman, Prairie Nest Records Scheme,

Box 1121,

Regina, Sask. 